\title{
Evaluation of commercially available antisera for serotyping of Pseudomonas aeruginosa
}

\author{
A. H. AL-DUJAILI AND D. M. HARRIS
}

From the Department of Medical Microbiology, University of Sheffield Medical School

SYNOPSIS Commercially available $O$ antisera have been compared with a standard pyocine typing method in the investigation of 156 strains of Pseudomonas aeruginosa. A third of the strains belonged to serotypes 3 or 6 and $42.3 \%$ to pyocine type 1 . Good differentiation of strains belonging to the predominant serotypes was achieved by pyocine typing. Although routine use of both methods provides a more complete discrimination between strains, the simplicity of serotyping renders it more suitable for use in the smaller laboratory, where only one method may be feasible. If desired, pyocine typing can be reserved for the strains which cannot be distinguished serologically.

In view of the frequency with which Pseudomonas aeruginosa is isolated in clinical practice, it is desirable that there should be an efficient method of typing this species for epidemiological purposes. Ideally, such a method should permit discrimination between the majority of strains. It should also be available to, and capable of being used by, a hospital diagnostic laboratory. Various workers have attempted serological subdivision of $P$ s. aeruginosa, the most generally accepted classification being that of Habs (1957), which is based on the identification of $O$ antigens. Typing antisera have not hitherto been commercially available in Britain, and most hospital laboratories which undertake typing of $P s$. aeruginosa have therefore relied on pyocine typing, either by the method of Darrell and Wahba (1964) or that of Gillies and Govan (1966). However, the Pasteur Institute range of $O$ antisera has recently been made available by A.P.I. Products Ltd. The basis of the Pasteur classification is that of Habs (1957), as modified and expanded by Véron (1961). It involves the use of 13 individual antisera which are also available in the form of three pools: A (types 1, 3, 4, 6, 10), B (types 2, 5, 7, 8), and C (types $9,11,12,13)$. This paper reports our experience with these antisera in the typing of hospital strains of Ps. aeruginosa.

\section{Materials and Methods}

A total of 156 strains of Ps. aeruginosa was collected from six Sheffield hospitals over a period of 11

Received for publication 9 April 1974. months. Of these, 132 were isolates from 130 patients situated in 33 wards or departments, and 24 were isolates from 18 different sites in one of the hospitals. Except in the case of two patients, from each of whom two strains of differing colonial types were examined, all strains were considered to be unconnected on clinical grounds. Primary identification was by the methods of Phillips (1969). All strains were pyocine-typed by the method of Gillies and Govan (1966), with subtyping of pyocine type 1 by the method of Govan and Gillies (1969). The serotypes were determined by slide agglutination, according to the manufacturers' instructions. However, these instructions do not specify the culture medium on which the strain should be grown before serotyping. Preliminary investigation revealed differences in the suitability of various media for this purpose. For example, when cultured on blood agar for 12 to 18 hours at $37^{\circ} \mathrm{C}$, many strains failed to agglutinate with either the pools or the monovalent sera. Using other methods, such strains were found to belong usually to one of the serotypes represented in pool A. Under similar conditions, most of the strains subsequently identified as belonging to group B agglutinated with the appropriate pool but failed to react with its component antisera. Group C strains were identified without difficulty. However, such strains formed a minority of the total (see below). Strains which failed to agglutinate were tested again after subculture; this was usually unsuccessful, especially with strains of the common type 6. Growth on Pseudomonas agar P (Difco) at $37^{\circ} \mathrm{C}$ was found to be more suitable for serotyping, but was still not entirely satisfactory. The best results 
were obtained from Trypticase soya agar (Difco) plus $5 \%$ horse blood, with incubation at $32^{\circ} \mathrm{C}$ for 18 hours. This was employed as the definitive method.

\section{Results}

The distribution of serotypes among the strains is shown in table I. A third of the strains was found to belong to two serotypes ( 3 and 6 ), and 21 strains $(13.6 \%)$ were not typable. Of the latter, five were non-agglutinable by any sera, 11 were autoagglutinable, and five were agglutinated by more than one monovalent antiserum $(1,3$, and 10 in four cases, and 5 and 7 in the remaining strain). If these strains showing cross reactions are excluded from consideration, the proportion of non-typable strains was $10 \cdot 3 \%$.

\begin{tabular}{llll}
\hline Serotype & $\begin{array}{l}\text { Number of } \\
\text { Strains }\end{array}$ & Serotype & $\begin{array}{l}\text { Number of } \\
\text { Strains }\end{array}$ \\
\hline 1 & $1(0.6 \%)$ & 8 & $13(8 \cdot 3 \%)$ \\
2 & $4(2.6 \%)$ & 9 & $6(3.9 \%)$ \\
3 & $32(20 \cdot 5 \%)$ & 10 & $8(5 \cdot 1 \%)$ \\
4 & $11(7.1 \%)$ & 11 & $10(6.4 \%)$ \\
5 & $11(7.1 \%)$ & 12 & 0 \\
6 & $21(13.5 \%)$ & 13 & $5(3.2 \%)$ \\
7 & $10(6.4 \%)$ & Non-typable & $21(13.5 \%)$ \\
\hline
\end{tabular}

Table I Serotypes encountered among 156 hospital strains of Pseudomonas aeruginosa

${ }^{1}$ Autoagglutinable $11(7 \cdot 1 \%)$, polyagglutinable 5 (3.2\%), nonagglutinable $5(3 \cdot 2 \%)$

One hundred and thirty-one of the strains could be allocated to recognized pyocine types (table II). A further 19 strains produced characteristic, though unclassifiable, patterns, and only six strains $(3.8 \%)$ showed no inhibition of the indicators. Two of these strains could be assigned to specific serotypes. Strains of pyocine type 1 were by far the commonest, representing $42 \cdot 3 \%$ of all strains. Fifty-seven strains of this type were subtyped with the results shown in table III, which compares the differentiation of the strains by the pyocine subtyping with that achieved

\begin{tabular}{llll}
\hline $\begin{array}{l}\text { Pyocine } \\
\text { Type }\end{array}$ & $\begin{array}{l}\text { Number of } \\
\text { Strains }\end{array}$ & $\begin{array}{l}\text { Pyocine } \\
\text { Type }\end{array}$ & $\begin{array}{l}\text { Number of } \\
\text { Strains }\end{array}$ \\
\hline 1 & $66(42.3 \%)$ & 11 & $1(0.6 \%)$ \\
2 & $4(2.6 \%)$ & 14 & $1(0.6 \%)$ \\
3 & $17(10.9 \%)$ & 19 & $1(0.6 \%)$ \\
5 & $7(4.5 \%)$ & 22 & $1(0.6 \%)$ \\
6 & $4(2.6 \%)$ & 27 & $1(0.6 \%)$ \\
8 & $2(1.3 \%)$ & 30 & $3(1.9 \%)$ \\
9 & $6(3.8 \%)$ & Unclassifiable & $19(12.2 \%)$ \\
10 & $17(10.9 \%)$ & No inhibition & $6(3.8 \%)$ \\
\hline
\end{tabular}

Table II Pyocine types encountered among 156 hospital strains of Pseudomonas aeruginosa

by serological typing. The pyocine subtyping allowed classification of all the strains, while serologically five $(8 \cdot 8 \%)$ were not typable. However, the strains which were serologically typable could be assigned to 10 serotypes as opposed to the eight pyocine subtypes.

The serological method, like pyocine typing, suffered from the disadvantage that a large number of strains belonged to predominant types, although this was less marked than with pyocine typing (serotypes 3 and 6 combined accounting for $34 \%$ of all strains, while pyocine type 1 alone represented $42.3 \%$ ). When pyocine typing was carried out on strains of serotypes 3 or 6 , it was found that 42 of the 53 strains could be allocated to 18 specific pyocine types, with only five strains belonging to the common pyocine type 1 .

\section{Discussion}

Provided that due attention was paid to cultural methods for propagation of the strains of $P s$. aeruginosa under test, the typing antisera were found to give a reliable differentiation of most strains encountered locally, only $10.3 \%$ being unclassifiable. A major disadvantage was the predominance of types 3 and 6 . However the alternative method (pyocine typing) also revealed a predominance of strains belonging to one type (type 1), a situation which has already been noted by other

\begin{tabular}{|c|c|c|c|c|c|c|c|c|c|c|c|c|c|}
\hline \multirow{2}{*}{$\begin{array}{l}\text { Pyocine } \\
\text { Subtype }\end{array}$} & \multirow{2}{*}{$\begin{array}{l}\text { Number of } \\
\text { Strains }\end{array}$} & \multicolumn{12}{|c|}{ Number of Strains Belonging to the Serotypes Shown } \\
\hline & & 2 & 3 & 4 & 5 & 6 & 7 & 8 & 9 & 11 & 13 & $N A^{1}$ & $A A^{2}$ \\
\hline 1(a) & 8 & 0 & 0 & 1 & 0 & 1 & 3 & 0 & 2 & 0 & 0 & 1 & 0 \\
\hline (b) & 10 & 0 & 1 & 4 & 0 & 1 & 0 & 0 & 0 & 3 & 1 & 0 & 0 \\
\hline (c) & 17 & 1 & 0 & 0 & 3 & 0 & 3 & 6 & 0 & 0 & 1 & 2 & 1 \\
\hline $1(\mathrm{~d})$ & 9 & 1 & 0 & 0 & 5 & 0 & 3 & 0 & 0 & 0 & 0 & 0 & 0 \\
\hline $1(\mathrm{e})$ & 1 & 0 & 0 & 0 & 1 & 0 & 0 & 0 & 0 & 0 & 0 & 0 & 0 \\
\hline I(f) & 5 & 0 & 0 & 1 & 0 & 1 & 0 & 0 & 3 & 0 & 0 & 0 & 0 \\
\hline $1(\mathrm{~g})$ & 2 & 0 & 0 & 0 & 1 & 1 & 0 & 0 & 0 & 0 & 0 & 0 & 0 \\
\hline l(h) & 5 & 0 & 0 & 2 & 0 & 0 & 0 & 1 & 0 & 11 & 0 & 1 & 0 \\
\hline
\end{tabular}

Table III Correlation of serotypes and pyocine subtypes in 57 strains of pyocine type 1 
workers (Govan and Gillies, 1969; Mushin and Ziv, 1973). If adequate discrimination is to be achieved by pyocine typing, the subtyping recommended by Govan and Gillies (1969) is essential.

A more complete discrimination between strains is achieved by routine use of both serotyping and pyocine typing. However if only one method is feasible, serotyping has certain advantages, provided that the distribution of types found here is typical of other localities. There is some evidence to suggest that this is so (Muraschi, Bolles, Moczulski, and Lindsay, 1966; Wretlind, Hedén, Sjöberg, and Wadström, 1973). The method is less time-consuming and less subject to interpretive error than pyocine typing, and hence may be more suitable for the smaller laboratory. The number of types which we could distinguish was virtually the same with both methods, but the percentage of strains allocated to predominant types was less with the serological method. Subdivision of serotypes 3 and 6 by the pyocine method produced a good discrimination, few strains of these serotypes belonging to the common pyocine type 1 ; a reduction in the work of the laboratory could therefore be achieved by employing the serological procedure as a primary classification, with pyocine typing reserved for subdivision of the predominant serotypes.
We are indebted to Dr J. Colquhoun and Professor M. G. McEntegart, who provided some of the strains examined, and to $\operatorname{Dr}$ R. R. Gillies who kindly supplied indicator strains for pyocine typing.

\section{References}

Darrell, J. H., and Wahba, A. H. (1964). Pyocine-typing of hospital strains of Pseudomonas pyocyanea. J. clin. Path., 17, 236-242.

Gillies, R. R., and Govan, J. R. W. (1966). Typing of Pseudomonas pyocyanea by pyocine production. J. Path. Bact., 91, 339-345.

Govan, J. R. W., and Gillies, R. R. (1969). Further studies in the pyocine typing of Pseudomonas aeruginosa. J. med. Microbiol., 2, 17-25.

Habs, I. (1957). Untersuchungen über die O-Antigene von Pseudomonas aeruginosa. Z. Hyg. Infektionskr., 144, 218-228.

Muraschi, T. F., Bolles, D. M., Moczulski, C., and Lindsay, M. (1966). Serological types of Pseudomonas aeruginosa based on heat-stable $\mathrm{O}$ antigens: correlation of Habs' (European) and Verder and Evans' (North American) classifications. $J$. infect. Dis., 116, 84-88.

Mushin, R., and Ziv, G. (1973). An epidemiological study of Pseudomonas aeruginosa in cattle and other animals by pyocine typing. J. Hyg. (Camb.), 71, 113-122.

Phillips, I. (1969). Identification of Pseudomonas aeruginosa in the clinical laboratory. J. med. Microbiol., 2, 9-16.

Véron, M. (1961). Sur l'agglutination de Pseudomonas aeruginosa: subdivision des groups antigéniques 0:2 et 0:5. Ann. Inst. Pasteur, 101, 456-460.

Wretlind, B., Hedén, L., Sjöberg, L., and Wadström, T. (1973). Production of enzymes and toxins by hospital strains of Pseudomonas aeruginosa in relation to serotype and phagetyping pattern. J. med. Microbiol., 6, 91-100. 